\title{
PENGEMBANGAN SISTEM INFORMASI LAYANAN AUDIO VISUAL PERPUSTAKAAN UNIVERSITAS PENDIDIKAN GANESHA BERBASIS VIDEO STREAMING
}

\author{
Putu Tika Parmawati ${ }^{1}$, Putu Sukayana ${ }^{2}$ \\ UPT Perpustakaan \\ Universitas Pendidikan Ganesha \\ Singaraja-Bali
}

\author{
Email: tika.parmawati@gmail.com ${ }^{1}$, nayorkcity@yahoo.co.id²
}

\begin{abstract}
Abstrak
Penelitian ini bertujuan untuk mengembangkan perangkat lunak sistem informasi layanan audio visual Perpustakaan Universitas Pendidikan Ganesha berbasis video streaming. Jenis penelitian ini merupakan Research and Development ( $R$ \& $D$ ) dengan metode pengembangan menggunakan model prototyping. Pengembangan sistem informasi layanan audio visual berbasis video streaming dengan enam tahap, yaitu : 1) Tahap pengumpulan kebutuhan dan perbaikan, 2) Tahap perancangan desain cepat (desain awal), 3) Tahap membangun prototipe, 4) Tahap evaluasi prototype, 5) Tahap perbaikan prototype, dan 6) Tahap rekayasa produk. Penentuan tingkat kelayakan aplikasi sistem informasi layanan audio visual berbasis video streaming berdasarkan uji validasi ahli bidang teknologi informasi dan uji coba terbatas pada pustakawan dan pemustaka. Hasil penelitian ini menunjukkan bahwa aplikasi sistem informasi layanan audio visual berbasis video streaming dapat menjadi alternatif pemberian layanan audio visual kepada pemustaka di perpustakaan, dapat memfasilitasi kebutuhan pemustaka dalam pemanfaatan koleksi audio visual yang dimiliki perpustakaan, dan ketersediaan arsip data koleksi audio visual dalam bentuk file digital yang tidak mudah rusak dan tidak mudah hilang.
\end{abstract}

Kata Kunci: Audio Visual, Video Streaming, Perpustakaan.

\begin{abstract}
Aim of this study to develop the software of audio visual services based on video streaming in the library of Ganesha University of Education. Research and Development (R \& D) design was applied in this study which was developed through prototyping models. The software was constructed through six stages, namely: 1) needs analysis and repairment, 2) rapid design (preliminary design), 3) prototypesbuilding, 4) prototype evaluation, 5) prototyperevisement, and 6) product adequacy. The validation of the software was determined by the experts in information technology and limited testing toward librarians and users. The results of this study on indicate that the application of audio visual information system services based video streaming can be an alternative provision of audio visual services to the library users, can facilitate the users need in using the
\end{abstract}


audio visual collections owned by the library, and the availability of audio visual archives in the form of digital files that are not easily damaged and lost as well.

Keywords: Audio Visual, Video Streaming, Library.

\section{PENDAHULUAN}

Penerapan Teknologi Informasi (TI) saat ini telah menyebar hampir di semua bidang tidak terkecuali di perpustakaan. Perpustakaan sebagai institusi yang bertugas mengelola bahan pustaka, baik berupa buku maupun bukan berupa buku (non book material) sehingga dapat digunakan sebagai sumber informasi oleh setiap pemakainya. Perkembangan TI dewasa ini memungkinkan seluruh kegiatan perpustakaan memanfaatkan teknologi informasi. Kebutuhan akan $\mathrm{TI}$ sangat berhubungan dengan peran dari perpustakaan sebagai kekuatan dalam pelestarian dan penyebaran informasi ilmu pengetahuan dan kebudayaan.

Implementasi TI secara optimal sangat diperlukan dalam layanan perpustakaan, karena sebagian besar pekerjaan-pekerjaan yang dilakukan di perpustakaan berupa layanan kepada pemustaka. Koleksi perpustakaan tidak hanya buku saja tetapi termasuk bahan bukan buku. Kehadiran bahan bukan buku ini memperkaya koleksi bahan perpustakaan dan memungkinkan perpustakaan memberikan layanan yang lebih bervariasi kepada pemustaka. Layanan audio visual atau pandang dengar merupakan salah satu jenis layanan yang diberikan kepada pemustaka.

Koleksi bahan perpustakaan yang termasuk dalam audio visual atau pandang dengar adalah kaset, film, slide, piringan hitam, compact disc $(C D)$, kaset video dan lain-lain. Perpustakaan Universitas Pendidikan Ganesha
(UNDIKSHA) menyediakan layanan audio visual dengan koleksi audio visual yang dimiliki dalam bentuk kaset tape dan $C D / D V D$. Koleksi kaset tape dan $C D / D V D$ yang dimiliki Perpustakaan UNDIKSHA sebagian besar berisi informasi yang berkaitan dengan bawaan buku yang ada di perpustakaan. Layanan audio visual yang dimiliki oleh Perpustakaan UNDIKSHA belum banyak dimanfaatkan oleh mahasiswa karena masih sedikit mahasiswa yang mengetahui keberadaan layanan tersebut. Disamping itu, koleksi audio yang dimiliki Perpustakaan UNDIKSHA masih berupa kaset tape sehingga kurang diminati dan dimanfaatkan oleh pemustaka.

Layanan audio visual di Perpustakaan UNDIKSHA masih bersifat manual, maksudnya mahasiswa yang ingin meminjam koleksi audio visual tersebut harus datang langsung ke perpustakaan. Pemustaka yang ingin meminjam koleksi audio visual sering mengalami kesulitan untuk mengetahui isi dari koleksi audio visual yang dimiliki perpustakaan. Hal ini disebabkan karena Perpustakaan UNDIKSHA belum memiliki ruangan khusus untuk menampilkan koleksi audio visual yang dimilikinya sehingga pemustaka harus mengecek sendiri isi dari koleksi audio yang ingin dipinjam. Untuk mengoptimalkan pemanfaatan koleksi audio visual yang dimiliki Perpustakaan UNDIKSHA maka perlu dibuatkan sebuah sistem yang dapat menampung koleksi audio visual dalam bentuk file digital dan dapat diakses secara 
bersamaan (live video streaming). Video streaming adalah tayangan langsung yang di-broadcast kepada banyak orang (viewers) dalam waktu yang bersamaan dengan kejadian aslinya, melalui media data komunikasi (network) baik yang terhubung dengan kabel atau wireless.

Pengembangan sistem informasi layanan audio visual berbasis video streaming dipilih menjadi alternatif pemberian layanan audio visual karena mampu mengatasi permasalahanpermasalahan diatas.

Sesuai dengan uraian latar belakang masalah, maka permasalahan yang akan dibahas yaitu: (1) Bagaimana rancang bangun Sistem Informasi Layanan Audio Visual Perpustakaan Universitas Pendidikan Ganesha Berbasis Video Streaming? (2) Bagaimana implementasi Sistem Informasi Layanan Audio Visual Perpustakaan Universitas Pendidikan Ganesha Berbasis Video Streaming?

Penelitian ini akan menghasilkan perangkat lunak sistem informasi koleksi audio visual berbasis video streaming, diharapkan dapat menjadi alternatif pemberian layanan audio visual kepada pemustaka di perpustakaan, dapat memfasilitasi kebutuhan pemustaka dalam pemanfaatan koleksi audio visual yang dimiliki perpustakaan, dan ketersediaan arsip data koleksi audio visual dalam bentuk file digital yang tidak mudah rusak dan tidak mudah hilang. Karakteristik aplikasi sistem informasi layanan audio visual yang tidak terbatas ruang dan waktu diharapkan dapat membantu pustakawan dalam memberikan layanan dan pemustaka dalam mendapatkan informasi, baik dalam satu wilayah maupun di luar wilayah.

\section{METODE}

Penelitian ini merupakan penelitian pengembangan perangkat lunak. Pada penelitian ini ada dua tahap utama, yaitu: pengembangan perangkat lunak dan uji coba (evaluasi) perangkat lunak. Tahapan penelitian ini adalah sebagai berikut.1) Membuat rancang bangun sistem informasi audio visual berbasis video streaming. Pembuatan rancang bangun meliputi kegiatan seperti: (a) Membuat diagram konteks (b) Membuat data flow diagram (c) Kegiatan dilaksanakan oleh ketua peneliti bersama anggota peneliti. Output dari kegiatan ini adalah rancang bangun sistem informasi audio visual berbasis video streaming. 2) Mengimplementasikan rancang bangun sistem informasi audio visual berbasis video streaming. Kegiatan implementasi rancang bangun seperti. (a) Membuat antarmuka program (interface) (b) Membuat koneksi (c) Mengintegrasikan fitur-fitur (d) Kegiatan dilaksanakan oleh ketua peneliti bersama anggota peneliti. Output dari kegiatan ini adalah sistem informasi audio visual berbasis video streaming; 3) Memasang (install) sistem informasi audio visual berbasis video streaming pada jaringan komputer, baik di intranet maupun di internet Kegiatan ini dilaksanakan ketua peneliti bersama anggota peneliti; 4)Melakukan uji coba sistem informasi audio visual berbasis video streaming dengan sampel terbatas. Sampel terdiri dari beberapa petugas perpustakaan dan mahasiswa Universitas Pendidikan Ganesha. Kegiatan ini dilaksanakan oleh ketua peneliti bersama anggota peneliti. Output kegiatan ini adalah pemanfaatan sistem informasi audio visual berbasis video streaming untuk mendukung 
layanan di perpustakaan; 5) Melakukan perbaikan (revisi) terhadap sistem informasi audio visual berbasis video streaming berdasarkan masukan dari pakar dan pengguna. Kegiatan ini dilaksanakan oleh ketua peneliti bersama anggota peneliti. Output kegiatan ini adalah sistem informasi audio visual berbasis video streaming yang telah direvisi.

\section{Metode Penelitian Rancang Bangun}

Penelitian ini merupakan pengembangan perangkat lunak, dengan sasaran akhir yang diharapkan adalah terbangunnya sebuah perangkat lunak (software) sesuai dengan spesifikasi yang ditetapkan. Oleh karena itu, metode yang digunakan mengikuti paradigma dalam pengembangan perangkat lunak. Dalam mengembangkan perangkat lunak terdapat banyak paradigma yang bisa digunakan, dan dalam program ini kami menggunakan salah satu jenis paradigma pengembangan yakni paradigma prototyping. Urutan langkah pada paradigma prototyping diilustrasikan dalam gambar di bawah ini.

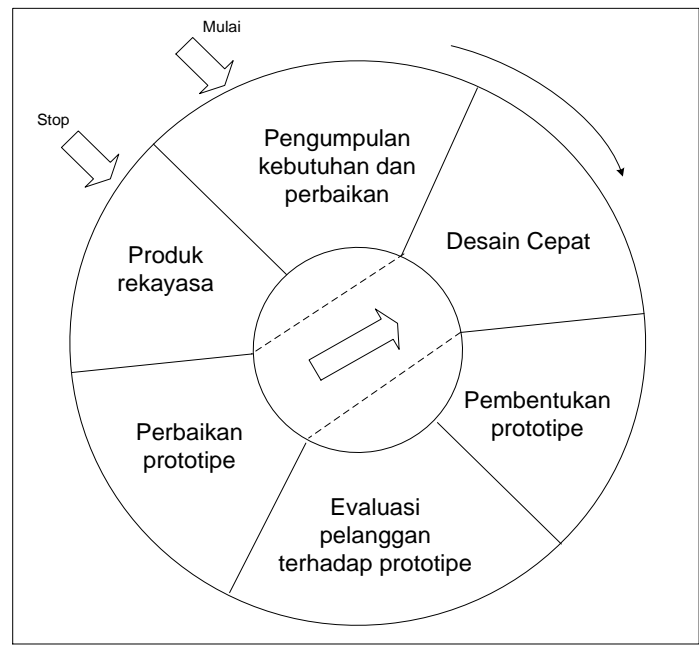

Gambar 1. Diagram Pengembangan Perangkat Lunak

Sesuai dengan mekanisme penelitian yang diilustrasikan pada gambar diatas, langkah utama dalam penelitian ini dapat diuraikan sebagai berikut. 1)Tahap pengumpulan kebutuhan dan perbaikan Pada tahap ini dilakukan pengumpulan data yang dibutuhkan untuk pengembangan sistem informasi audio visual berbasis video streaming dan pengumpulan informasi kebutuhan perangkat lunak dan perangkat keras pendukung. Data diperoleh dengan teknik observasi dan pengumpulan informasi kebutuhan perangkat lunak dan perangkat keras dilakukan dengan studi literatur. Data yang dikumpulkan dianalisis untuk mendapatkan algoritma untuk pengembangan sistem, sedangkan informasi perangkat lunak dan perangkat keras pendukung 
dianalisis untuk mendapatkan komposisi perangkat lunak dan perangkat keras yang ideal untuk mendukung pengembangan sistem informasi audio visual berbasis video streaming. 2) Tahap perancangan desain cepat (desain awal) Algoritma yang telah tersusun pada tahap sebelumnya dipergunakan untuk merancang desain awal dari produk yang akan dibangun yang biasanya masih bersifat global. Untuk langkah awal, perancangan desain cepat terutama dapat dilakukan pada bagian tampilan. 3) Tahap membangun prototype Berdasarkan desain awal yang telah ditetapkan maka mulai dilakukan pengimplementasian untuk memperoleh produk yang diharapkan. Pekerjaan pada tahap ini belum menyentuh aspek detai dari perangkat lunak yang dibangun. Tujuan pembangunan prototype untuk mempermudah proses dari perangkat lunak yang dibangun. Ada 3 jenis prototipe yaitu: (a)prototipe di atas kertas; (b) prototipe kerja,yaitu prototipe yang telah diimplementasikan ke dalam bahasa pemrograman, sehingga dapat dieksekusi namun belum berjalan sempurna; dan (c) prototipe jadi, yaitu prototipe yang telah jadi tapi mungkin masih perlu disesuaikan dengan kebutuhan pengguna. 4)Tahap evaluasi prototype Pada tahap ini dapat dilakukan evaluasi terhadap prototipe yang dihasilkan sehingga produk akhir semakin bagus dan kemungkinan kesalahan produk semakin kecil. Evaluasi dilakukan dengan melibatkan pakar TIK, beberapa petugas perpustakaan UNDIKSHA dan beberapa mahasiswa UNDIKSHA untuk menilai operasional dan keterpakaian sistem informasi audio visual berbasis video streaming.

5)Tahap perbaikan prototype Berdasarkan evaluasi oleh pengguna jika telah sesuai dengan yang diharapkan makatahapan dilanjutkan ke rekayasa produk. Jika ada kesalahan maka akan diperbaiki, sesuai tanda panah dalam diagram, langkah pengerjaan kembali lagi pada langkah desain cepat dan seterusnya hingga prototipe tersebut sesuai dengan yang diharapkan. 6)Tahap rekayasa produk Pada tahap inilah produk benar-benar telah diimplementasikan hingga diperoleh hasil akhir yang siap digunakan.

Pembuatan sistem informasi audio visual berbasis video streaming melibatkan dua bidang keahlian, yaitu di bidang perpustakaan dan di bidang teknologi komputer. Oleh karena itu, pengembangan sistem informasi audio visual berbasis video streaming melibatkan pakar dari kedua bidang tersebut. Dalam pelaksanaan penelitian, secara rinci prosedur kerja yang dilakukan adalah seperti pada gambar 2. 


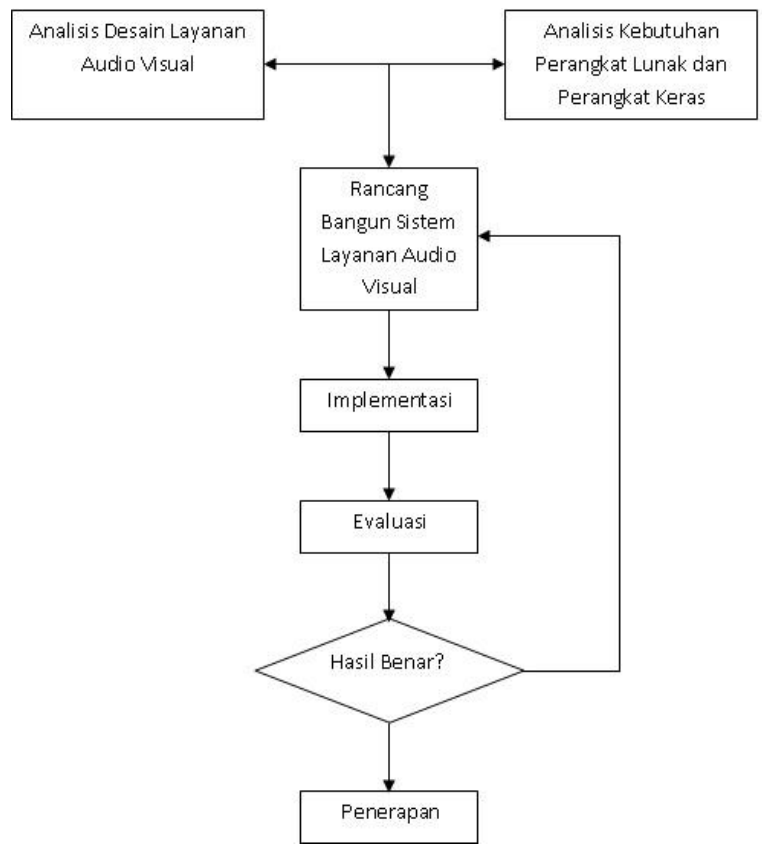

Gambar 2. Prosedur Kerja Pengembangan Perangkat Lunak

Analisis desain layanan audio visual dilakukan oleh pustakawan. Pada desain layanan audio visual dirumuskan hal-hal sebagai berikut.

a) Koleksi audio visual apa saja yang dilayankan pada sistem informasi layanan audio visual.

b) Bagaimana mekanisme mengunggah koleksi audio visual ke sistem informasi layanan audio visual.

c) Bagaimana mekanisme mahasiswa yang ingin memanfaatkan koleksi audio visual pada sistem informasi layanan audio visual.

d) Siapa yang mengatur hak akses untuk tiap-tiap pengguna, apakah langsung administrator atau pihak lain yang harus ditugaskan. e) Bagaimana pengklasifikasian koleksi audio visual di sistem informasi layanan audio visual, apa menurut jenisnya atau berdasarkan klasifikasi sederhana.

Setelah proses analisis desain layanan audio visual sudah selesai, maka dilanjutkan pada tahap penyusunan rancang bangun sistem informasi layanan audio visual berbasis video streaming. Rancang bangun yang dikembangkan mencakup: a) diagram konteks, dan b) data flow diagram (DFD). Rancang bangun yang tersusun kemudian diimplementasikan menjadi perangkat lunak sistem informasi layanan audio visual berbasis video streaming. Komponen-komponen sistem informasi layanan audio visual diimplementasikan mencakup: a) 
antarmuka program (interface), b) koneksi (link) dan c) fitur-fitur layanan. Komponen-komponen tersebut kemudian diintegrasikan menjadi produk akhir perangkat lunak sistem informasi layanan audio visual berbasis video streaming.

Perangkat lunak sistem informasi layanan audio visual berbasis video streaming yang sudah jadi kemudian dievaluasi. Evaluasi dilakukan oleh pakar dan pengguna. Berdasarkan evaluasi oleh pakar dan pengguna, dilakukan revisi terhadap sistem informasi layanan audio visual berbasis video streaming. Revisi dapat dilakukan mulai dari rancang bangun dan seterusnya hingga implementasi atau revisi pada implementasi saja, tergantung kesalahan yang terjadi.

\section{Metode Ujicoba}

Perangkat lunak sistem informasi layanan audio visual berbasis video streaming yang sudah dikembangkan kemudian dimasukkan file digital koleksi audio visual. Selanjutnya, perangkat lunak tersebut diujicoba oleh pakar dan pengguna sistem. Pakar melakukan penilaian perangkat lunak dengan mengobservasi bagian internal program dan mencoba menjalankannya. Menurut Candiasa (2012) beberapa indikator penilaian terhadap perangkat lunak yang dihasilkan adalah kebenaran atau ketepatan operasional sistem, kemampuan program untuk mengantisipasi kondisi abnormal dalam menjalankan fungsinya, kemudahan untuk mengadaptasikan program bila terjadi perubahan spesifikasi, keberadaan program untuk bisa dipergunakan kembali baik sebagian atau seluruhnya untuk aplikasi lain, efisiensi terhadap sumber daya, kemudahan program ditransfer ke perangkat keras yang berbeda, kemudahan untuk menelusuri kegagalan program dan validasi, kemampuan program memproteksi diri dari penggunaan dan modifikasi, pengaturan program dalam modul-modul, dan keterbacaan program oleh orang lain selain programmer.

Setelah mengobservasi bagian internal sistem informasi layanan audio visual berbasis video streaming dan mengobservasi hasil eksekusi program, pakar melakukan penilaian menggunakan instrument di atas. Pada kolom kualifikasi penilai menuliskan kualifikasi sangat baik, baik, cukup baik, kurang dan sangat kurang, sesuai penilaian pakar. Pakar juga diminta untuk menuliskan komentar secara umum kinerja perangkat lunak pada kolom yang disediakan.

Rekomendasi pakar dari hasil ujicoba ditindaklanjuti dengan proses perbaikan perangkat lunak. Setelah dilakukan perbaikan perangkat lunak, selanjutnya dilakukan ujicoba terhadap beberapa pustakawan dan pemustaka di Perpustakaan UNDIKSHA. Indikatorindikator penilaian yang digunakan antara lain kecepatan akses, kecepatan login, tampilan layout, fitur-fitur pada aplikasi, ukuran font dan kepantasan sebagai layanan audio visual bagi pengguna.

\section{HASIL DAN PEMBAHASAN}

Analisis data pendukung
pengembangan sistem informasi
layanan audio visual perpustakaan
Universitas Pendidikan Ganesha
berbasis video streaming menghasilkan
rancang bangun dengan spesifikasi
sebagai berikut :(1) Sistem informasi


layanan audio visual yang dapat dioperasikan baik di intranet maupun internet, sehingga diperlukan administrator untuk mengendalikannya;(2) Pengguna sistem informasi audio visual adalah pemustaka di UNDIKSHA (seluruh civitas akademika UNDIKSHA yang menjadi anggota perpustakaan);(3)
Aktivitas yang dapat dilakukan pada sistem informasi layanan audio visual mencakup : a) aktivasi user; b) input kategori koleksi audio visual; c) upload koleksi audio visual; d) melihat koleksi audio visual;dan e) forum. Diagram kasus pemakai (diagram use case) sistem informasi layanan audio visual dapat digambarkan seperti gambar 3 .

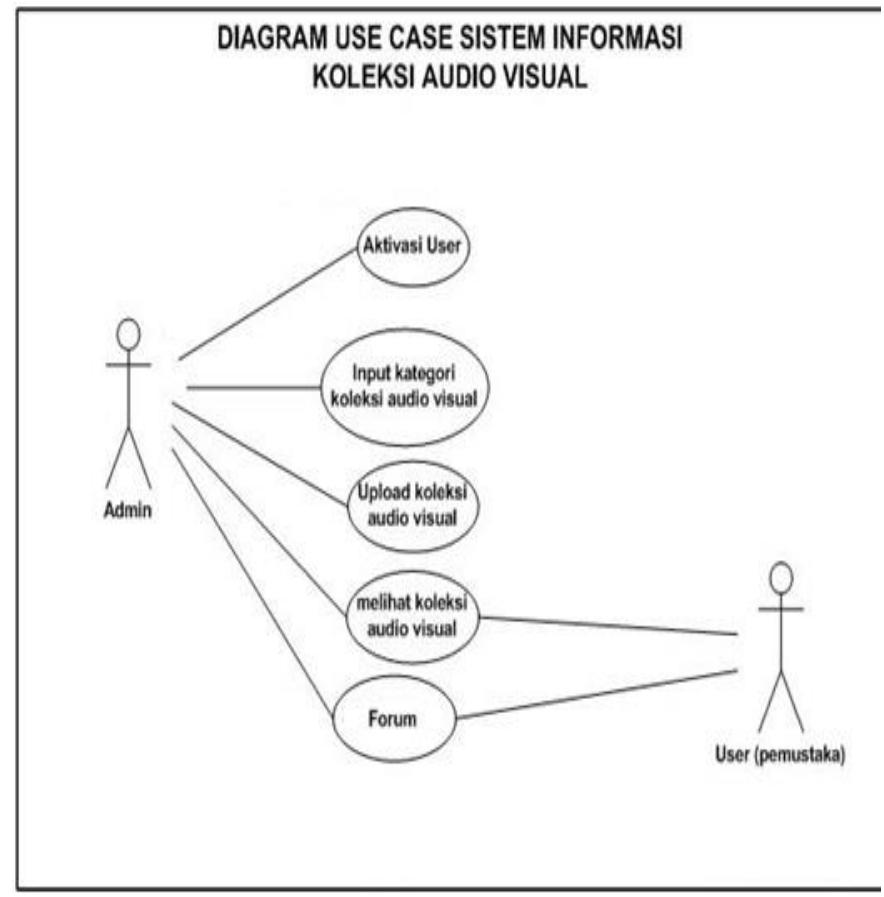

Gambar 3. Diagram use case sistem informasi koleksi audio visual

Administrator punya hak untuk input kategori koleksi audio visual yang dimiliki perpustakaan. Administrator juga berhak upload koleksi audio visual sesuai dengan kebijakan kepala perpustakaan. Selain itu administrator juga berhak melakukan aktivasi useryaitu menambah keanggotaan pemustaka atau menghapus keanggotaan pemustaka yang sudah wisuda dan pensiun. Pemustaka mempunyai hak untuk melihat koleksi audio visual yang dimiliki oleh perpustakaan. Seluruh civitas akademika UNDIKSHA dapat mengakses koleksi audio visual yang dimiliki perpustakaan setelah mendaftar menjadi anggota perpustakaan. Deskripsi fungsional perangkat lunak sistem informasi koleksi audio visual digambarkan menggunakan diagram 
alur data (data flow diagram /DFD) seperti tampak pada Gambar 4.

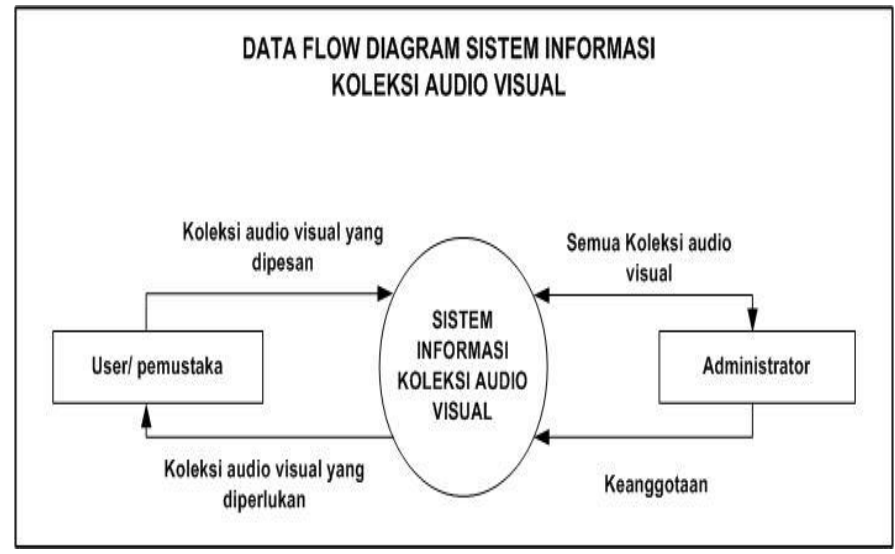

Gambar 4. Data flow diagram sistem informasi koleksi audio visual

Hasil rancang bangun sistem informasi koleksi audio visual yang telah dibuat, selanjutnya diimplementasikan menjadi perangkat lunak dengan menggunakan PHP sebagai bahasa pemrograman, MySql sebagai basis data pendukung, Linux Ubuntu 10.04 Server sebagai sistem operasi. Ffmpeg dan Ruby sebagai aplikasi pendukung audio visual, dan Apache sebagai web server.

Sistem informasi koleksi audio visual yang telah diimplementasikan untuk memfasilitasi layanan audio visual yang dimiliki perpustakaan. Perpustakaan UNDIKSHAn sejak tahun 2013 tidak mengijinkan pemustaka untuk meminjam koleksi audio visual hal ini terkait dengan adanya undangundang hak cipta. Sedangkan perpustakaan tidak memiliki ruang koleksi audio visual yang dilengkapi fasilitas untuk menampilkan koleksi audio visual. Sistem informasi koleksi audio visual memberi kemudahan bagi pemustaka untuk melihat koleksi audio visual yang dimiliki perpustakaan, sehingga dapat menjadi alternatif untuk memfasilitasi layanan audio visual di perpustakaan UNDIKSHA.

Sistem informasi koleksi audio visual dibangun untuk mengoptimalkan pemberian layanan di perpustakaan. Sistem ini diharapkan mampu bertindak sebagai pemberi layanan audio visual kepada pemustaka di lingkungan UNDIKSHA. Layanan utama yang diharapkan dari sistem ini adalah menampilkan koleksi audio visual yang dimiliki perpustakaan. Pemustaka dapat melihat koleksi audio visual secara langsung melalui jaringan internet pada web perpustakaan tanpa boleh mengunduh/ mendownload. Dengan demikian, koleksi audio visual yang dimiliki perpustakaan dapat dimanfaatkan secara optimal oleh pemustaka secara mandiri.

Sistem informasi koleksi audio visual menyajikan beberapa wujud koleksi audio visual yang dimiliki perpustakaan antara lain koleksi audio 
visual berupa video, koleksi audio visual berupa gambar, dan koleksi audio visual berupa suara. Beberapa fitur yang disediakan dalam sistem ini adalah: 1) halaman upload koleksi audio visual, 2) halaman melihat koleksi audio visual, 3) Halaman Registrasi dan Login Pengguna, 4) Halaman Manage User List, 5) halaman Input Manage Kategori Koleksi Audio Visual, dan 6) Halaman Forum.

Perangkat lunak sistem informasi koleksi audio visual yang dikembangkan mengikuti tahapan metodologi prototyping telah diimplementasikan pada uji terbatas pengguna sistem. Pengujian perangkat lunak dilakukan melalui beberapa pola pengujian, yakni uji kelayakan oleh pakar teknologi informasi dan uji keterpakaian oleh pustakawan dan pemustaka. Hasil uji coba oleh pakar teknologi informasi menunjukkan bahwa perangkat lunak sistem informasi koleksi audio visual sudah memenuhi unsur kebenaran fungsi sistem informasi sesuai spesifikasi yang ditentukan, yakni sebagai pemberi layanan audio visual. Ketegaran sistem untuk mengantisipasi kondisi abnormal juga sudah dipandang cukup sepanjang tidak berhubungan dengan konektivitas. Kemampuan perangkat lunak untuk beradaptasi bila terjadi perubahan spesifikasi dinilai sudah cukup. Efisiensi sistem dalam pemanfaatan sumber daya memang dinilai masih perlu upaya, terutama bila koleksi audio visual yang disajikan dalam bentuk video. Portabilitas program untuk ditransfer ke lingkungan perangkat keras yang berbeda sudah didukung oleh fasilitas sistem operasi serta perangkat lunak pengembang yang digunakan. Verifikasi untuk menelusuri kegagalan program baik masih dalam validasi maupun setelah operasi dinilai cukup mudah dilakukan. Integritas perangkat lunak untuk memproteksi diri dari penggunaan dan modifikasi masih perlu ditingkatkan. Kejelasan pengaturan modul-modul serta keterbacaan perangkat lunak oleh orang lain selain programmer dinilai sudah cukup. Masukan yang diberikan oleh pakar adalah aplikasi layanan audio visual perlu mempertimbangkan ukuran file koleksi audio visual yang diunggah.

Aplikasi sistem informasi audio visual selain diuji oleh pakar bidang teknologi informasi, juga sudah diuji kelayakan dan kenyamanan penggunaan oleh beberapa pustakawan. Hasil uji coba menunjukkan bahwa kecepatan akses perhalaman web dan kecepatan login ke sistem dipandang baik sepanjang tidak berhubungan dengan konektivitas. Kecepatan akses ke koleksi file audio visual dalam bentuk teks, gambar dan suara dinilai baik, sedangkan kecepatan akses ke file audio visual dalam bentuk video dipengaruhi oleh ukuran filenya. Tampilan layout design interface aplikasi sistem informasi layanan audio visual dan ukuran tulisan dinilai sudah sesuai. Fitur-fitur yang disajikan dalam aplikasi sistem informasi layanan audio visual dinilai sesuai dan berguna untuk kebutuhan layanan audio visual. Aplikasi sistem informasi layanan audio visual dinilai mudah digunakan dan dapat digunakan sebagai alternatif pemberian layanan audio visual. Masukan yang diberikan oleh pakar adalah aplikasi layanan audio visual perlu adanya sosialisasi bagaimana proses alih media koleksi audio visual yang dimiliki 
perpustakaan sehingga dapat diunggah. Hasil ujicoba terhadap beberapa pemustaka memberikan hasil yang tidak jauh berbeda dari hasil uji coba terhadap pustakawan.

Temuan di atas menunjukkan bahwa aplikasi sistem informasi layanan audio visual berbasis video streaming dapat menjadi alternatif pemberian layanan audio visual di perpustakaan dan dapat memfasilitasi pemustaka dalam memanfaatkan koleksi audio visual yang dimiliki perpustakaan. Secara umum hasil uji coba adalah sebagi berikut. 1) Aplikasi sistem informasi koleksi audio visual cukup layak untuk digunakan sebagai alternatif pemberian layanan audio visual di perpustakaan, sehingga dapat mengatasi keterbatasan sarana prasarana dalam layanan audio visual. 2) Aplikasi sistem informasi koleksi audio visual membantu pustakawan dalam memberikan layanan audio visual kepada pemustaka, sehingga dapat mengoptimalkan pemberian layanan di perpustakaan. 3). Aplikasi sistem informasi koleksi audio visual membantu pustakawan dalam memperkenalkan koleksi audio visual yang dimiliki perpustakaan. 4) Aplikasi sistem informasi koleksi audio visual membantu memfasilitasi pemustaka yang ingin mendapatkan informasi koleksi audio visual yang dimiliki perpustakaan. 5) Ketersedianya arsip data koleksi audio visual dalam bentuk file digital yang tidak mudah rusak dan tidak mudah hilang.

\section{SIMPULAN}

Aplikasi sistem informasi layanan audio visual berbasis video streaming dikembangkan mengikuti paradigma prototyping sebelum diimplementasikan. Aplikasi sistem informasi layanan audio visual berbasis video streaming dapat bertindak sebagai alternatif pemberi layanan audio visual kepada pemustaka di Perpustakaan UNDIKSHA, dan dapat memfasilitasi pemustaka dalam memanfaatkan koleksi audio visual yang dimiliki perpustakaan. Karakteristik aplikasi sistem informasi layanan audio visual yang tidak terbatas ruang dan waktu diharapkan dapat membantu pustakawan dalam memberikan layanan dan pemustaka dalam mendapatkan informasi, baik dalam satu wilayah maupun di luar wilayah.

Aplikasi sistem informasi koleksi audio visual telah diuji melalui beberapa pola pengujian, yakni uji kelayakan oleh pakar teknologi informasi dan uji keterpakaian oleh pustakawan dan pemustaka. Hasil uji coba adalah 1) Aplikasi sistem informasi koleksi audio visual cukup layak untuk digunakan sebagai alternatif pemberian layanan audio visual di perpustakaan, sehingga dapat mengatasi keterbatasan sarana prasarana dalam layanan audio visual. 2) Aplikasi sistem informasi koleksi audio visual membantu pustakawan dalam memberikan layanan audio visual kepada pemustaka, sehingga dapat mengoptimalkan pemberian layanan di perpustakaan. 3). Aplikasi sistem informasi koleksi audio visual membantu pustakawan dalam memperkenalkan koleksi audio visual yang dimiliki perpustakaan. 4) Aplikasi sistem informasi koleksi audio visual membantu memfasilitasi pemustaka yang ingin mendapatkan informasi koleksi audio visual yang dimiliki perpustakaan. 5) Ketersedianya arsip data koleksi audio visual dalam bentuk file digital yang 
tidak mudah rusak dan tidak mudah hilang.

Untuk meningkatkan manfaat pengembangan aplikasi sistem informasi koleksi audio visual berbasis video streaming disarankan kepada pustakawan untuk mengunggahkoleksi audio visual yang dimiki perpustakaan sehingga koleksi audio visual yang disajikan dalam aplikasi ini semakin lengkap sehingga membantu pemustaka dalam mendapatkan informasi yang diperlukan.Aplikasi ini masih memiliki kelemahan, pustakawan sebagai pengunggah koleksi audio visual harus menyeleksi koleksi audio visual yang layak dimanfaatkan oleh pemustaka, sehingga informasi yang disajikan bersifat positif.

Aplikasi informasi layanan audio visual berbasis video streaming masih terbuka untuk dikembangkan baik secara teknis maupun ide. Untuk itu, kepada semua pihak yang berminat disarankan untuk bersama-sama mengembangkan aplikasi ini dalam upaya peningkatan mutu layanan di Perpustakaan UNDIKSHA .

\section{UCAPAN TERIMA KASIH}

Penghargaan dan terima kasih diberikan kepada Direktur Pembinaan Penelitian dan Pengabdian kepada Masyarakat (Ditbinlitabmas) Direktorat Jenderal Pendidikan Tinggi Depdiknas, yang telah memberikan bantuan dana sehingga penelitian ini dapat berjalan sesuai rencana dan keinginan peneliti. Penelitian ini dibiayai dari dana DIPA Universitas Pendidikan Ganesha dengan SPK No: 103/UN48.14/PL/2014, Tanggal 6 Maret 2014.

\section{DAFTAR PUSTAKA}

Arhami M. 2011. "Bahan Kuliah Pertemuan 10 Rekayasa

Perangkat Lunak Data Flow Diagram (DFD) dan Kamus Data" Tersedia pada http://arhami.files.wordpress.com/

2011/08/bahan-kuliah_dfd.pdf

(diaksestanggal 20 juni 2013)

Azizah dan Fery Siswadi. (2011). ElibISIS. Jurnal Pustakawan Indonesia Volume 11 No 2.

Bafadal Ibrahim. (2005). Pengelolaan Perpustakaan Sekolah. Jakarta. Bumi Aksara.

Candiasa, I Made, dkk. 2012. Pemerataan dan Peningkatan Mutu Peningkatan Melalui Komunitas Guru Online. Laporan Penelitian DIPA. Lembaga Penelitian UNDIKSHA .

Darmono.2007. Perpustakaan Sekolah Pendekatan Aspek Manajemen dan Tata Kerja. Jakarta: Grasindo

Harif, M. 2004. Membangun Database Berbasis Open Office dan MySQL. Jakarta: Dian Rakyat.

Irmayanti. (2011). Pengembangan Perpustakaan Digital Puslata UT dalam Mendukung Sistem Belajar Jarak Jauh. Jurnal Teknologi Pendidikan Volume XV No 2.

Nugroho, Bunafit. 2004. Pemrograman Web Dinamis dengan PHP dan MySQL. Yogyakarta: Gava Media.

Yakub. 2012. Pengantar Sistem Informasi. Yogyakarta : Graha IImu.

Peranginangin, Kesiman. 2006.Aplikasi WEB dengan PHP MySQL. Yogyakarta: ANDI OFFSET.

Jurnal Sains dan Teknologi|564 
Perpustakaan UNDIKSHA . 2012. Buku Panduan Perpustakaan Universitas Pendidikan Ganesha. Singaraja: UNDIKSHA .

Suyanto, Muhammad. 2005. Teknologi Informasi. Yogyakarta: ANDI OFFSET.

Sidik, B. 2004. Pemrograman web dengan PHP. Bandung: Informatika.

Sulaiman, Amir Hamzah. 1988. Media Audio Visual Untuk Pengajaran,
Penerangan dan Penyuluhan. Jakarta: Gramedia.

Sumardji, P. 2000. Pelayanan Refrensi Di Pepustakaan. Jakarta: Erlangga.

Sihombing. 2009. AdobeDreamweaver CS3 dan PHP. Yogyakarta: Andi.

Wiswakarma, K. 2009. Membuat Katalog Online dengan PHP dan CSS. Yogyakarta: Lokomedia. 